\title{
DOCUMENTARY CONSTITUTIONS NOTES CONCERNING A COMPARATIVE INQUIRY
}

\author{
By G. F. M. van DeR TANG
}

\section{Decline of constitutionalism?}

After all that has been written on the subject, "constitutionalism" appears to be a term hardly serviceable for scientific purposes. Apart from it frequently being used as an ideologically determined, appealing catchword, the term simply denotes too much. Rather loosely the "constitutionalism" of the Greek City-State and of the Roman Republic is written about and from there broad lines are drawn to "modern constitutionalism" as if to suggest that the situations and issues at stake and the problems to be solved are in any way comparable. Maybe the term becomes more manageable if strictly applied to the complex of principles and convictions that were characteristic for liberal thought on state and law in the nineteenth century. However, as there seems to be, at least in a number of western countries, a certain consensus about a main objective of what is commonly called constitutionalism, i. e. the quest for limitation and control of political power and the primacy of "the legal" above "the political", the term is used here in this sense.

The phenomenon documentary constitution ${ }^{1}$ has for a long time primarily been associated with liberal-democratic thought on the arrangement of public power and the relationship between citizens and government. By the end of the eighteenth and throughout the nineteenth centuries constitutionalism ${ }^{2}$ was the dominant ideology in the political domain. It meant the promise of limited government and self-determination, the liberation of man from the chains of feudal relations and monarchic absolutism, and it was a watchword for the successive nationalist movements. A written constitution, at least containing a bill of rights and some version of the trias politica would prevent concentration of power and thereby ensure freedom to the citizens.

However, the conception of the basic objectives of the documentary constitution as a necessary prerequisite for constitutional government did in the long run not hold its pretended exclusive position. The international labour movement and the sharp criticisms of Marx and Engels as to the capitalist characteristics of the constitutions of their time and the rather one-sided devotion of constitutionalism to property-rights and the freedom of contract did in large measure discredit the concept of constitutionalism as the sole answer to the need for rationalization

\footnotetext{
1 For the purpose of this article documentary constitution is formally defined as a politico-legal document or a set of documents that in a certain state is designated as enjoying a special legal authority or to which otherwise particular qualities are attached in order to distinguish it from other legal documents.

2 The concept of constitutionalism still draws considerable attention in politico-legal science. To mention a few important teeatises from the postwar period: Carl Joachim Friedrich, Constitutional Government and Democracy (2nd ed. 1964); Charles Howard McIlwain, Constitutionalism, Ancient and Modern (1950); M. J. C. Vile, Constitutionalism and the Separation of Powers (1967); Karl Loewenstein, Political Power and the Governmental Process (2nd ed. 1965, esp. part 2); Paolo Biscaretti di Ruffía, Introduzione al diritto costituzionale comparato (1970); Francis D. Wormuth, The Origins of Modern Constitutionalism (1949); C. F. Strong, Modern Political Constitutions (7th. ed. 1966); Ottó Bihari, Socialist Representative Institutions (1970, esp. ch. I and IV); Georges Burdeau, Traité de Science Politique (2nd ed. 1969, T. IV); B. O. Nwabueze, Constitutionalism in the Emergent States (1972).
} 
of the political process and adjustment of social relations. What after the First World War had remained of the long-cherished "Verfassungsideal" did almost entirely disappear with the collapse of the Weimar Republic and contemporary political regimes that were given shape by constitutions set up from the optimistic premise that a well-framed constitutional order embodied in a document might prove itself a stabilizing factor in hazardous socio-political and economic conditions. Especially the failure of the Weimar Constitution has given occasion to a decrease of expectations as to what a documentary constitution with respect to politics may actually accomplish. A further change of optics was caused by the emergence of completely new types of documentary constitutions that widely deviated from the traditional patterns, precedented by such documents as the Mexican revolutionary constitution of 1917 with its extensive Labor Charter and the first constitution of the RSFSR (1918). They prepared the way for a series of documentary constitutions that gave expression to the social, economic and cultural aspects of politics in a manner quite unimaginable for constitutional lawyers of the classical type. Moreover, the impetus given to the process of constitution making after the two World Wars and especially the mass of constitutions of new states since 1945, proclaimed before, while and after attaining their independence from the former colonial powers, resulted in a dazzling variety of constitutional models. The documentary constitution appears to be employed, to whatever purpose, by all conceivable types of government on the liberal-authoritarian $a^{2} \mathrm{~s}^{3}$, a feature which only proves one thing: that the documentary constitution appears to be able to pay service to every species of political regime and to every political ideology. Apart from other connotations, "constitutionalism" stands for legality and something like decent political behaviour. For that reason the term will probably never be struck off the politico-legal vocabulary. However the evolution is indicative of the stage of general decline of constitutionalism as traditionally conceived, at least of the process of dissociation between the concept of constitutionalism and the phenomenon documentary constitution.

\section{Constitution and political reality}

No survey of the evolution of the documentary constitution will stop at the recognition that all national states of the world with the notable exception of course of Great Britain and a few other countries ${ }^{4}$ have provided themselves with such a document. Everyone who is interested in the subject will be aware of the circumstance that documentary constitutions are operative in states wherein concordance between the constitutional prescripts and the political process is a

3 Cfr. Jean Blondes, An Introduction to Comparative Government, 1969, p. 249.

4 Besides Great Britain, Saudi Arabia, Bhutan and the Sultanate of Oman happen to be the only national states wheren the absence of a documentary constitution is unquestionable. Burundi and Togo form a case by themselves. In Blaustein and Flanz' collection Constitutions of the Countries of the World for these republics resp. the Charter of the Party of Unity and National Progress UPRONA and the Statutes of the Rally of the Togolese People are filed next to a number of ordinances, whereby no mention is made whether these documents are considered by the states themselves as their documentary constitutions. Although Israel and Spain are commonly considered as countries without a documentary constitution, a good case may be made for concluding that the total of their respective Basic Laws and Leyes Fundamentales together constitute multi-documentary constitutions, as in the case of e. g. Finland and Sweden. In the case of Canada and New Zealand it is difficult to determine whether the acts that compose the written part of their "constitution", must be qualified as their documentary constitution, or solely the British North America Act and the Constitution of New Zealand Act. All depends on the definition one wishes to use. 
standing rule as well as in states wherein deliberate non-compliance is or is said to be the order of the day. The discrepance between the solemnly declared constitutional text and the way it is implemented is an old issue. However, since the appearance, now thirty years ago, of Werner Kägi's highly impressive "Die Verfassung als rechtliche Grundordnung des Staates", signalizing next to an alarming loss of normativity a general enfeeblement of the idea of constitution, the discussion has remarkably been intensified. Karl Loewenstein may be attributed the honor of having elucidated the problem of normativity by the introduction of his well-known classification of normative, nominal and semantic constitutions ${ }^{5}$. Loewenstein stipulates that the question whether a constitution should be characterized as normative, nominal or semantic cannot be decided, as a rule, from its text alone, since constitutions are usually silent on some of the most essential parts of the power process, such as electoral system, political parties, and plural groups ${ }^{6}$. But the author himself is equally silent about the crucial question as to who may be considered as capable and ideologically unbiased to a sufficient degree to decide in which category a particular constitution should be placed. Nor does Benjamin Akzin, while examining documentary constitutions as to their stability or fragility and their reality, make clear who might be the "realistic observer" he refers to in the beginning of his article?

Both Loewenstein and Akzin, though basically supporters of documentary constitutions, show a clear scepticism toward their value and the names of many others, including Wheare, Burdeau, even Friedrich perhaps, may be added. It is the scepticism of those scholars who may be called the constitutionalists, who, with the ancient conception of the documentary constitution in one hand and the facts and features of the frequent violations and breaches of constitutions in the other, cannot but come to the conclusion that the documentary constitution in many parts of the world has become a function rather than a determining factor of government ${ }^{8}$ and that constitutions by their very nature are not suited to meet the realities of political life ${ }^{\theta}$.

The constitutionalist tradition can be perceived in less subtle statements too. Whenever it is asserted that in many states the documentary constitutions merely serve as a kind of democratic façade behind which a sinister power process is going on, the lack of accordance between the constitutional norms and political reality is generally pointed at. Here again the basic assumption is that the measure wherein limited government has been attained is the ultimate yardstick for determining the effectiveness of the constitution.

\footnotetext{
5 Karl Loewenstein, Reflections on the Value of Constitutions in Our Revolutionary Age, in Arnold J. Zurcher (ed.), Constitutions and Constitutional Trends since World War II, 1951, pp. 191-224. A french version appeared in the Revue française de science politique, 1952, pp. 5-23, 312-335. See further Political Power and the Governmental Process, 2nd ed. 1965, pp. 147-153 (Verfassungslehre, 1959, pp. 152-157); Verfassungsrecht und Verfassungsrealität, in Beiträge zur Staatssoziologie, 1961, pp. 430-480. The ontological classification has been discussed by a. o. Leslie Wolf-Phillips, PostIndependence Constitutional Change in the Commonwealth, Political Studies, 1970, pp. 19-21: Other references are to be found in Harry Eckstein, Constitutional Engineering and the Problem of Viable Representative Government, in Eckstein and Apter, Comparative Politics, 1963, p. 98, Paavo Kastari, Uber die Normativität und den hierarchischen Vorrang der Verfassungen, in K. D. Bracher (ed.), Die moderne Demokratie und ihr Recht, 1966, p. 68; Franz Ronneberger, Verfassungswirklichkeit als politisches System, Der Staat, 1968, p. 40; Wilhelm Geck, Die völkerrechtlichen Wirkungen verfassungswidriger Verträge, 1963 , p. 13.

6 Political Power, p. 150.

7 Benjamin Akzin, On the Stability and Reality of Constitutions. In R. Bachi (ed.), Studies in Economic and Social Sciences, Scripta Hierosolymitana, 1956, vol. III, pp. 313-339. Constitutions have a valid claim to reality if they reflect the existing power relations and are obeyed in fact.

8 Akzin, op. cit. p. 326

9 Georges Burdeau, Zur Auflösung des Verfassungsbegriffs, Der Staat, 1962, p. 392.
} 
However the problem may be approached along other lines too, proceeding from the point of view that the objectives of limited government and control of power by means of a respected but in political practice often ignored document relate to only one of many aspects of documentary constitutions. And however it may be that expectations and demands of this kind with regard to constitutions have been repeated in other political cultures, the constitutionalist conception seems not to hold its dominant position any longer ${ }^{10}$.

Viewed in this light the time seems to be ripe for a reappraisal of the position of documentary constitutions in the socialist-communist orbit. It has been a wellpreserved custom to describe particularly the constitution of the Soviet Union of 1936 as mainly a vehicle for propaganda both domestic and international. The absence of separation of powers, the shadow of an omnipotent party behind the formal state structure and the fact that the enlightened catalogue of rights did apparently not protect the Soviet citizens against arbitrary action by party and governmental organs, were fully emphasized. Especially in the period of the Cold War, "Soviet constitutionalism" used to be pictured in mirthless and on the whole rather hostile prose ${ }^{11}$. However it should be noticed that a work like Vyshinski's official restatement of the constitutional law in the Stalin era ${ }^{12}$ hardly invited dialogue. In later years the climate obviously improved, of which an excellent article of the German scholar Ferdinand O. Kopp, Das Verfassungsverständnis in den sozialistischen Staaten, offers a good example ${ }^{\mathbf{1 3}}$. One of his conclusions concerns the growing inner importance of the socialist constitutions, not only as an instrument in the hands of the party but also as an arrangement of social life desired by the people itself, which the party, standing itself outside the constitutional order, can simply no longer ignore. On the other side socialist authors too, a. o. Stefan Rozmaryn and the Hungarian István Kovács, have done much to foster understanding for the socialist conception of constitution ${ }^{\mathbf{1 4}}$.

However a statement as made by Rozmaryn that in comparison with the material guarantees for the implementation of civil and political rights, the legal guarantees for their enforcement as offered by the socialist constitutions occupy a minor place ${ }^{15}$, should make clear that this conception still differs to a considerable extent

10 Cf. Kastari's criticism where Loewenstein passes judgement on the constitutions of the developing countries (for the greater part nominal) and the socialist-communist states (semantic), apparently on the base of criteria solely derived from the liberal-democratic conception of state. Kastari, op. cit. p. 68.

11 So e. g. Robert G. Neumann, Constitutional Documents of East-Central Europe, in Zurcher, op. cit. pp. 175-190; Samuel L. Sharp, New Constitutions in the Soviet Sphere, 1950; Julian Towster, Political Power in the USSR, 1948; Merle Fainsod, How Russia is Ruled, rev. ed. 1963. The more recent studies of authors like John Hazard, Gordon Skilling, Walter Grottian and Adam Ulam show a less rigid approach. However, noteworthy are some remarks made by the latter in his treatment of the Russian political system (Beer and Ulam, Patterns of Government, 2nd ed. 1968, pp. 656 and 658). "Does not Soviet constitutionalism work against the regime in the sense that the, rights proclaimed in the Constitution are belied every day by the facts of Soviet politics? Does not the average citizen resent the gap, say, between the provisions of the Constitution as to free elections and the reality, in which the Communist Party nominates a single list of candidates who are then elected without opposition?"... Ulam admits that "the legal and constitutional framework is secondary to the real complex of political, police and social forces upon which the regime rests. Yet examples are not lacking in which in a situation of crisis an institution that has existed on paper without interfering with the essence of political power suddenly became endowed with importancen.

12 Andrei Y. Vyshinski, The Law of the Soviet State, translated from the Russian by Hugh W. Babb. Nor did more popular propaganda-books such as V. Karpinsky, The Social and State Structure of the U.S.S.R. (1953), although its comparison of the social rights of American and Soviet workers makes for funny reading.

13 In: Recht und Staat, Festschrift für Günther Küchenhoff, 1972, pp. 573-603.

$14 \mathrm{Cfr}$. Stefan Rozmaryn, Quelques questions de la théorie des constitutions socialistes, in Liber amicorum baron Louis Fredericq, 1965, vol. II, pp. 881-900, and La Constitution comme loi fondamentale de l'Etat socialiste, in Biscaretti di Ruffía and Rozmaryn, La Constitution comme loi fondamentale dans les Etats de l'Europe occidentale et dans les Etats socialistes, 1966, pp. 79-129; István Kovács, New Elements in the Evolution of Socialist Constitution, 1968.

15 Biscaretti and Rozmaryn, op. cit. p. 113. Meanwhile, the number of "western-democratic" constitutions 
from the idea of constitution as commonly held in Western political thought. Whatever stress may be laid in socialist legal literature upon problems of normativity and the observance of legality ${ }^{16}$, the main objectives of the socialist constitutions must be found elsewhere. Clearly instrumental functions of the constitution as a set of principles and basic regulations underlying the socialeconomic and political order take the place of the concepts of limited government and dispersion of power. While in socialist literature the constitutions of the Western-democratic type are regarded as instruments of the ruling class for oppressing and exploiting the working people, the socialist constitutions are supposed to confirm and strengthen the latter's supremacy in its efforts to build up a communist society. Integration and mobilization may be considered as important objectives of the socialist constitution. This is best illustrated by the usual nation-wide discussions concerning constitutional drafts, the way these are organized and their results published. Focusing public attention upon a new constitution and mobilizing the citizens in connection with it, may safely be considered - and not only for the constitutions of the socialist-communist states - an effective means for socio-psychological anchorage of realization and acceptance of political goals.

\section{A different approach}

The views expressed in this article are by no means inspired by a desire to do away with the idea of the documentary constitution as a rationalizing and restraining factor in the governmental process and as a legal guarantee for the due exercise of political power. However, it should be emphasized that this concept is no universal one. About the generalization that the purpose of a constitution is to limit the powers of government, S. A. de Smith has stated that it is far too wide and, indeed on the contemporary African scene, largely irrelevant ${ }^{17}$. The social, economic and cultural problems of the new nations demand other solutions than offered by the idea of government under law; the frequent revolutions and coups d'etat, civil wars and insurrections, and the replacement of democratic and parliamentary institutions by military and charismatic regimes form sufficient proof of this. Further, the circumstance that politics apparently follow their own line and that everywhere constitutions are virtually changed without formal amendment, by political practice, by conventions and usages, leaves hardly any room for a conception whereby the documentary constitution is a set of fundamental rules supposed to govern the political process. Reappraisal of its nature and scope might open perspectives for new approaches to the problem.

Most literature on documentary constitutions, based on the old conception of what a constitution is or should be, is concerned with rather limited aspects of

that for instance provide for judicial protection of civil rights (cfr. art 19(4) of the constitution of the Federal Republic of Germany and the relevant articles of the European Convention) will show itself to be remarkably small. In this respect the charges of window dressing could be reverberated as well.

16 Cfr. Ottó Bihari, Constitutionalism and Legality, Acta Juridica, 1964, pp. 99-118; P. F. Martinenko, $\mathrm{K}$ normatívno - právnej povahe ústavnych noriem a ich forme, Pravny Obzor, 1968, pp. 497-506; A. P. Kosycin, Voprosy razvitija sozialisticheskich konstitutsii, Sovetskoe Gosudarstvo i Pravo, 1965,

pp. 144-149 (concerning a congress on the evolution of socialist constitutions in Szeged 1964); A. Ch. Machnenko, Gosudarstvennoe pravo zarubezjnich sozialisticheskich stran, 1970.

17 Stanley Alexander de Smith, Legislatures under Written Constitutions, in Sir Alan Burns (ed.), Parliament as an Export, 1966, p. 213. 
the relationship between documentary constitution and politics. Other approaches, like system analysis, network analysis and interaction analysis, either inside or with respect to constitutions, would enable to examine problems that so far received only scarce attention. A functional analysis for example will be less interested in problems of normativity but rather in the effects of the existence of documentary constitutions in given political systems, the centripetal action of various political forces on constitutions, the influence of constitutions upon political change. Equally do questions concerning specific functions of documentary constitutions with respect to politics arise: What functions of constitutions are operative in which type of social and political system and in which mutual connection; what consequences does loss of functionality of the documentary constitution have for the political system.

The American political scientist Ivo Duchacek recently analysed the documentary constitutions of national states within what may be called a functional framework. "Over 100 national constitutions"; he writes in the preface of one of his books, "have been dissected to identify similarities and isolate the different circumstances of their creation, their patterns of existence, and their often premature deaths 18 ". Duchacek's main themes are the documentary constitutions and their bills of rights as political documents and as political acts. He is less concerned with their legal and organizational aspects. The organizational part of the constitution is called by him a power map, a blueprint for political action expressed in legal terms. To him the nonlegal, declamatory portions of a constitution play as important a role as its legal and organizational chapters. In this context Duchacek considers the functions of documentary constitutions with respect to communication and political socialization of utmost importance. And indeed, such importance cannot be denied if one is ready to admit, whatever the form wherein the various constitutions may be shaped and whatever their substance, that they are intended to embody a number of messages urging at a certain way of political behaviour and a certain attitude toward the political system. Some messages may be addressed to public office-holders, dispersing competences among them in minute detail and carefully prescribing how to act in what circumstances. Other messages are directed to the broad mass of citizens, offering them their scheme of political action, freedom of speech and of the press, freedom of assembly and association, other participatory rights like the suffrage, guarantees against unlawful intrusion of their rights by public authorities, and in many instances, guarantees or promises for their social, economic and cultural well-being. In this way the constitution functions as one of the ingredients in the process of political communication and may serve the purposes of political socialization and integration. Duchacek quotes Friedrich's well-known statement that constitutions "are symbolic expressions of the unifying forces in a community and they are supposed to strengthen them further ${ }^{19}$ ".

Generating interest of the general public for the constitution and its making might prove to be of value for enlarging its involvement with government affairs; commanding loyalty and respect for the constitution might promote political obligation and reinforce the regime's legitimacy. This might especially be true for

18 Ivo D. Duchacek, Power Maps - Comparative Politics of Constitutions, 1973. See further by the same author, Rights and Liberties in the World Today, 1973.

19 Duchacek, Rights and Liberties, P. 26. 
those newly established states where because of ethnical and linguistic diversity the concept of the national state, based on a politico-philosophical tradition and on societal relations that do not make part of the native cultural heritage, is an alien ${ }^{20}$. By articulation and aggregation of community interests the documentary constitution functions as an instrument of social engineering. There seems to be no reason why the effectivity of documentary constitutions in this respect should not be measured too, even when the legal-normative side is apparently neglected and when it is beyond doubt that many of them are serving quite other purposes than the objectives of restraint and control.

On the preceding pages attention has been paid to some of the problems one meets when studying documentary constitutions. We may know a good deal about them, but the exact nature of the phenomenon remains unclear. It will not be an easy task to explain the simple fact of the existence of documentary constitutions all over the world unless one contents oneself with considering it merely as a result of historical evolution with its roots in the idea of contract. A specific difficulty lies in the circumstance that the science of constitutional law so far has failed to offer a method through which the evaluation of the functioning of constitutions may be carried out without lapsing into casuistry. The science of constitutional law is still lacking an all-comprising theory on constitutions ${ }^{21}$.

The fact that nearly all states of the world have gone through the process of constitution making and that documentary constitutions apparently play a role in their legal systems and operation of government renders it worth trying to get more, and more systematic knowledge about the subject.

\section{An inquiry into constitutional texts}

The Division for Constitutional Law of the Faculty of Social Sciences of the Erasmus University at Rotterdam has recently started a research project concerning the texts of the constitutions of the national states of the world. In a sense the inquiry is an attempt to pass beyond the domain of speculation about the nature of documentary constitutions. The theory of constitutions is in essence an intrinsically unempirical branch of science, built upon a complex of abstract and more or less elaborated notions and ideas. If empirical data are applied, they serve for the purposes of evidence and adstruction rather than as a starting-point for theoretical reflection. The present inquiry is not dealing with the opinions on the scope and nature of documentary constitutions as expressed in literature, but turns itself to the constitutional texts themselves, the documents. Except for a number of questions concerning historical and geographical features none of the 215 questions included in the questionnaire may be answered from other sources than the constitutional texts. Data drawn from the texts might in further inquiries be correlated with information regarding demographic, socio-economic,

20 On this problem Nwabueze, op. cit. pp. 24-25.

$21 \mathrm{Cfr}$. the concluding remark of Herbert Krüger to his article in this review, "Stand und Selbstverständnis der Verfassungsvergleichung heute" (1972, p. 28): "Letztes, aber wohl unerreichbares Ziel einer dermaßen sich verstehenden Verfassungsvergleichung ist eine Verfassungslehre, die mittels einer Kombination von Empirie und Deduktion ein System von Lagen und Antworten vorlegen kann, das theoretisch seinen Gegenstand erschöpft und der Verfassunggebung Anregungen zur Erkenntnis ihrer Lagen und der hierauf möglichen Antworten vermitteln kann." 
cultural and socio-political features of the several countries. On the basis of these systematically collected and processed materials further insights may be obtained as to the functions of documentary constitutions with respect to the political systems of the world.

As source of inquiry choice was made for the only supplementary edition in the English language of all national constitutions, A. P. Blaustein and G. H. Flanz, Constitutions of the Countries of the World (Oceana Publications, Dobbs Ferry, N. Y., 197122).

The analysis of the contents of the constitutions is based on a selection of five items. Both the relationship between the constitutions and the structure of government will be examined and the position of constitutions within legal systems, because these items pre-eminently have reference to the domain of regulation of documentary constitutions. Furthermore it will be attempted to examine the similarities and divergences of their outward structure and composition. An important place take the questions in connection with the problems of constitutions as instruments of state- and nation building and regarding the constitution as an embodiment of universal values and norms.

The scheme of analysis for the stage of computer-processing provides for enumeration of the answers given to every single variable, i. e. straight runs of frequencies of given answers. It also provides for enumeration of the answers given to two or more variables, although this does not imply that the inquiry is set up in order to verify already elaborated hypotheses; its character is in the first place an exploring one. Yet it may be noted that cross-tabelling will result in answers to such (arbitrarily chosen) questions as:

- What is the average age of constitutions that establish judicial review of legislation and what is the average age of constitutions that do not establish judicial review;

- What percentages of the documentary constitutions promulgated respectively before 1918, between 1918 and 1945, and after 1945 contain provisions concerning the general responsibilities of the state with regard to society and people;

- What percentage of the constitutions referring to the equality of men and/or equal rights of man contain specific provisions prohibiting forms of discrimination;

- What percentage of the constitutions referring to religious values do also refer to people's sovereignty;

- What are the percentages (for successive periods) of the constitutions contain-

22 Cf. the review by K. R. Simmonds, International and Comparative Law Quarterly, 1974, pp. 208-209.

Of all existing collections of constitutions only three have come into consideration, because of their worldwide character and their recent date of publication. One of them, Peaslee's Constitutions of Nations (rev. 3rd. ed. The Hague 1965-70) seriously suffers from its design: since it is not set up as a supplementary edition it was already out of date at the moment of publication. The second, Corpus Constitutionnel (Leiden, 1968) would because of its impressive scientific approach, with excellent summaries of the constitutional structure of the several states and publication of the original constitutional texts next to a french translation, be highly useful for the purpose of this inquiry, but the work advances very slowly. Blaustein and Flanz offer the advantage of a supplementary edition which in all likelihood will be completed in 1975 . The collection is set up as a loose-leaf edition. By now 14 volumes have been published. Supplements are sent out several times a year. Of each state a concise political and constitutional history is given, the English text of the constitution in force and an annotated bibliography of primary and secondary sources and background materials.

The choice of Blaustein and Flanz has more or less been the result of a process of negative selection. The actuality of the constitutional texts delivered make this edition the only acceptable alternative. Yet serious doubts may be raised as to its reliability.

In the first place it should be noted that the materials are collected and adapted by different 
ing a general declaration on the separation of powers and of the constitutions not containing such a statement;

- What are the percentages of extensive and of concise constitutions promulgated in successive periods.

Two of the items of the inquiry will be considered in more detail below.

\section{Constitutions and universal values and norms}

As universal ${ }^{23}$ values may be denoted those understanding and convictions about good or bad and right or wrong, those preferences and rejections that are operative at a given time all over the world as guiding principles of human behaviour. In the context of this inquiry we have especially in mind values that stand at the base of contemporary conceptions of man about the nature of government and its relationship to the societal environment, the observance of which largely depends on the government's actual conduct. In this connection values may be mentioned like man's dignity and freedom, equality of men, justice, welfare, self-determination, peace, social justice, people's sovereignty, democracy and constitutional government.

Norms in this context are collectively shared, more or less binding expectations as to acting or not acting under certain conditions, or, in a more specific sense, concrete rules for conduct, established commands and prohibitions for behaviour of man in a given community. When we in the context of this inquiry speak of universal norms we refer to those basic norms with regard to the structure and operation of government that may be said to have obtained worldwide support, for instance judicial independence, responsible government, secret ballot, public meetings of representative bodies, observance of legality, the prohibition of degrading treatment and rights and freedoms of the individual.

The question is posed whether documentary constitutions may be considered to have as a common feature the embodiment of universally accepted values and norms with regard to the organization and operation of government. This part of the inquiry (containing no less than 92 questions in the questionnaire) is not meant to demonstrate that there exists something like "a universal constitutional law". It rather departs from the assumption that constitution-makers whatever their intentions may be, seek to give a legal basis to more general standards for governmental behaviour by not merely committing themselves to e. g. the Univer-

contributors. There is a wide variety of instances who translated and delivered the constitutional texts. Sometimes a photomechanical reprint is given of a paper obtained from an embassy or consulate-general, sometimes a copy of a constitution as printed in an Official Gazette, sometimes the source of information is an intergovernmental organ like the Pan American Union. Surely, such inconvenience cannot be avoided in an undertaking like this. Yet, on examining the constitutional texts one should be warned that in the process of translation they have already been subject to interpretation and adaptation as well, whereby the only check upon the reliability of the translations is interpretation and adaptation as well, whereby the only check upon the reliability of the translations is
the authorization by the governments of the countries themselves. There are some more problems. It appears to be that the collection is not restricted to documentary constitutions alone. In many instances other legal documents, like independent acts, are given prior or in addition to the documentary constitutions. Sometimes the editors present an unqualified number of documents without an indication which document(s) and on what grounds, may be considered as the state's documentary constitution. So one of the first problems to be solved in the actual inquiry is to determine whether a state has a documentary constitution or not and which of the inserted documents is the documentary constitution of a state.

23 In this text the word "universal" is not meant to denote values and norms that might prevail in every type of society irrespective of time, place and socio-cultural conditions (Cf. on universal norms, Robert Bierstedt, The Social Order, 4th ed., 1974, pp. 178-179). It denotes nothing more than worldwide presence without a claim to absolute validity. 
sal Declaration of Human Rights, but also by inscribing them in their national constitutions. Maybe it has to do with the desire for international - and domestic - acceptance: by inscribing such standards one may suggest that a certain level of political and cultural development has been attained. However the results of the inquiry might point to quite other directions.

\section{State- and nation-building}

The instrumentality of the documentary constitution implies its importance as a vehicle of state- and nation-building. Both notions are, in spite of the vast amount of literature on these subjects, still lacking a clear-cut definition. However they may conveniently be circumscribed as respectively denoting the process of the establishment, formation and arrangement of a state and the process of integration of the population into a national community and involvement of the people with national goals and interests. The first documentary constitution of a state is invariably considered as a major symbol of its establishment and, in many instances, a certificate of evidence that the stage of political maturity has been attained. This symbol-function is by no means to be reserved solely for the mass of constitutions that resulted from the postwar decolonization-process. The documentary constitution has, as stated by Karl Loewenstein, "for the last one and a half centuries become the symbol of nationhood and statehood, of selfdetermination and independence. No nation emerging from foreign domination in the successive waves of nationalism that have swept the world since the French Revolution has failed to give itself, of ten with a great deal of travail, by a free act of original creation, a written document embodying the fundamentals of its future existence $^{24}$ ". Certainly, one may point, with respect to the new states, to the elements of international habit-forming and "me-tooism": „New and wouldbe nations need constitutions to discuss and display regardless of their expected uses, simply because the established nations have them ${ }^{25}$." However constitutions are not only birth-certificates and their proclamation is more than just a moment in the political development of a nation. Constitutions do also reflect the hopes and aspirations of the people, or maybe more properly formulated, those of the political elite who substitutes its priorities and demands for those of the whole community. In this respect the total of constitutional preambles or otherwise titled introductory chapters may perhaps show itself to be mainly a rich and colourful depository of political doctrine and ideological phraseology ${ }^{26}$, but the impact of such appeals must never be underestimated. This might especially be the case with respect to those preambles that refer to such values like the unity of the

24 Loewenstein, Political Power, p. 135. Cfr. also Benjamin Akzin, The Place of the Constitution in the Modern State, Israel Law Review, 1967, p. 1, and François Luchaire, Les Constitutions et les Institutions administratives des Etats nouveaux: Aspect Juridique, in: Les Constitutions et les Institutions administratives des Etats Nouveaux, Bruxelles, Incidi, 1965, p. 601-602.

25 Duchacek, Power Maps, p. 11.

$26 \mathrm{Cfr}$. the preamble of the constitution of Tunesia (1957): "We declare that a republican regime is the best guarantee for safeguarding human rights..."; art I constitution of Liberia (derived from the preamble of the constitution of Massachusetts): "The end of the institution, maintenance and administration of government, is to secure the existence of the body politic, to protect it, and to furnish the individuals who compose it, with the power of enjoying in safety and tranquility, their natural rights..."; One even meets preambles referring to the purposes of the document their natural rights ". "The; One even meets preambles referring to the purposes of the document particular point of time is to provide a specific guide to organize the people's progress toward the future..." (preamble constitution of Syria 1969). 
nation, the nation's own identity and the cultural patrimony, the introduction of which might help to overcome social and cultural cleavages. The same is true for references to the nation's history, e. g. a national revolutionary movement and social and political conditions in the pre-revolutionary period.

Expositions of the current political doctrine and definition of national goals and interests are frequently accompanied by declarations on governmental tasks and responsibilities. Policy-intentions are usually followed by chapters containing a blueprint for the social and economic regime and the social and economic rights of the citizens.

The nationalist content of many documentary constitutions does not take an end with the more or less emotional appeals in their introductory parts. Frequently provision is made for a number of national symbols like the flag, the national anthem, the capital, the emblem, the preservation of monuments of national importance, a national flower, national animals and the like, and references to a national language and a national religion ${ }^{27}$. A further remark should be made. The consequences of the largely derivative character of many of the (first) constitutions of decolonized countries have vividly been discussed in literature. One cannot escape the impression that there exists a tension between the nationalist, more or less eloquent but least of all legalistic wordings of their preambles and the rather dull and matter-of-fact formulations of the "body of the constitution" which moreover usually shows few real autochtonous elements. This is true both for the constitutions of the new states of francophone Africa as well as for the constitutions of the so-called Westminstermodel. India, the constitution of which is a case by itself because of the introduction of a curious mixture of foreign constitutional arrangements, has intrinsically met the same problem. Here too, the requirement of continuity in administrative practice (Government of India Act) played a substantial role. Nevertheless, objections were already raised at the time of the Constituent Assembly with respect to the apparent absence of references to the "Indian spirit" and the Hindu tradition. One of the representatives is reported to have complained: "We wanted the music of Veena or Sitar, but here we have the music of an English band ${ }^{28}$."

In the present inquiry the questions having regard to the item of nation building are categorized as follows.

a) Questions concerning provisions on national symbols like the flag, the coat of arms, the capital, the national anthem, art-treasures and monuments;

b) Questions concerning provisions that are otherwise intended to reinforce political integration and commitment to the nation. Under this heading are classed questions that refer to the birth of the state, a revolutionary movement, the territory, a duty of citizens to take part in the development of the

\footnotetext{
27 Duchacek reveals that the animal kingdom is well represented in constitutional chapters dealing with national symbols. "The 'constitutional animals' constitute an unruly zoo dominated by eagles, tigers, panthers, leopards and lions... Tame animals are in a definite minority but horses (Mongolia) kangaroos and emus (Australia) and song birds are represented." (Power Maps, p. 29). The national kangaroos and emus (Australia) and song birds are represented." (Power Maps, p. 29). The national politico-lyrical expression. Noteworthy is the theme of Sibelius' Finlandia as a personal choice of Col. Ojukwu for the national anthem of former Biafra. However the prize for the most remarkable provision in this respect should be awarded to Art. 1 of the constitution of Equatorial Guinea of 1973: "The national anthem shall be that sung by the people on the day of proclamation of independence

28 Granville Austin, The Indian Constitution: Cornerstone of a Nation, 1966, p. 325.
} 
country or to participate in public affairs, a national language, a national religion, protection of the rights and culture as well as integration of social and/or ethnical minority groups etc.

The answers to the questions referred to above might give an indication as to what measure particular constitutions devote themselves to the efforts of nation building. Moreover the scheme of analysis provides for correlation of these questions with other variables like the year of establishment of the state and the number of constitutions since that time proclaimed, the geographical position, a possible colonial past, the form of government etc. Examples of such cross-tabel questions are:

- Do constitutions of states decolonized after 1945 proportionally make more provision for elements of nation building than constitutions of states where colonial rule took an end before 1945;

-Do constitutions that make mention of ethnical and/or sociocultural minority groups proportionally make more provision for nation building than constitutions that do not.

The same type of questions may be posed as to the distinction in federal and unitary states, one party- and multipartistates, states with a republican and with a monarchical form of government, socialist and non-socialist states etc. Other issues that may be examined are for example the use of symbols in constitutions of one-partystates, in newly independent states and the relationship of the constitution as an instrument of nation building and the stability of the constitutional and political order.

\section{Concluding note}

Documentary constitutions, whatever their source of authority, the type of government given shape by them and the purposes they are destined to serve, present an interesting point of departure for further theory-generation in the field of comparative constitutional law. Legal scientists, when confronted with the many instances of violation and breach of constitutions, where naked power speaks the last word against all juridified values and norms, react sometimes indignantly, sometimes dejectedly. However it might be asserted that the conviction long ago accepted in the field of private law that the law, written in statute, and in other species of prescript or decision is modified and set aside by societal development, has insufficiently penetrated the domain of the science of constitutional law. On the other side, documentary constitutions might prove themselves to be of greater importance for the political process than legal scientists in their despondency would be ready to assume, although this importance will perhaps manifest itself in quite another sense than traditionally demanded by constitutionalism whenever the relationship between law and politics was discussed.

The idea of constitutionalism is in need of reappraisal. The concept of documentary constitution should be reconsidered as well. Next to the problem of the legalnormative effectivity of the documentary constitution more attention should be paid to its effectivity in the socio-political and socio-psychological field. Not every constitution is so much a venerated document and a bulwark to be stable enough to resist such political storms as the controversy between Federalists and 
Democrats about 1800, the Civil War and Reconstruction, the contest around the New Deal and the Watergate affair as the constitution of the United States has proved to be. Nor does every constitution meet so much respect and caution when its fundamentals are concerned as those of most Western European countries. However that does not mean that the others should be considered as being merely waste paper in the political process. Comparative examination of documentary constitutions as to their contents may bring about further insights as to nature and effects of the phenomenon on the contemporary political scene. 


\section{On Military Regimes in Developing Countries}

\section{BY Herbert KRÜGER}

The analysis of military regimes in the Third World is hampered by an commitment to outdated concepts of the 19th century. The view of the soldier as a rapist of constitutional government and democracy leads to unwarranted generalizations and endangers a serious discussion of the causes of military take-overs. In this study (which will be supplemented and published as "Beiheft No. 8" of this Quarterly) an attempt will be made at a careful typology of military regimes in the Third World. For this purpose the term "military regime" has to be defined more precisely. "Military" refers not to armed bands, private armies, rule by invaders, warlordism, but to the army as a state-created institution. An military "regime" has to be distinguished from a "garrison-state" or a situation where the army is merely an important pressure group; or assumes influence as an arbiter in political conflicts (as "guardian of the constitution", or supporters of a civilian politician). One can only speak of a military regime, if there is a commanding influence of the army on government, and if the army perceives its rule as a public service. This will usually mean that a military regime is not intended as a permanent solution but as a provisional substitute for constitutional institutions that have failed to perform their functions.

\section{Documentary Constitutions - Notes concerning a comparative inquiry}

\section{By Ger F. VAN DER TANG}

Nearly all national states of the world have placed a single document or, in some instances, a limited number of documents at the top of their legal order and political system. In this way the documentary constitution has turned out to be one of the more successful exports of Western political thought. Yet it is abundantly clear that the documentary constitution has drifted far away from the "natural climate" of its emergence: the idea of constitutionalism, heavily leaning upon such concepts as limited government and power control. The documentary constitution as it appears now, is a multi-purpose instrument, and not an exclusive attribute of any particular type of government or political ideology.

Nowadays it is almost a platitude to point at the lack of accordance between constitutional texts and the actualities of political life. Numerous examples may be supplied in order to illustrate the feebleness of the documentary constitution in front of the machinations of the power process. And although the assertion may be right that the constitution, representing the formal-normative moment of reality, makes integral part of that reality too, so that the contradistinction is in essence a false one, distrust as to the usefulness of the documentary constitution may well be explained.

On the other side, the universality of the phenomenon documentary constitution and its apparent suitability in widely different political systems, still offer an interesting challenge to politico-legal science. Next to the legal-normative aspects of constitutional documents, attention should be paid to their effectivity 
with regard to communication and integration. Appreciation of documentary constitutions as to their performance in these fields might open perspectives for a reappraisal of their position in the political systems of the world. The instrumentality of the documentary constitution with regard to the efforts of nation building and the constitution as an embodiment of universal values and norms are two of the items to be examined in the course of an inquiry of constitutional texts at the University at Rotterdam. The research-project is set up in order to contribute to further insight into nature and functions of the documents concerned.

\section{The Demands of the Developing Countries for a "New" International Economic Order}

\section{By Rainer Tetzlaff}

This article analyses the demands of the developing countries (DC) for a "new" international economic order, the chances for their realization, and their consequences for the structure of the international division of labor between industrial metropoles and periphery-countries.

The more empirical part of the article is based on a content-analysis of the resolutions of the Third World conferences in Cocoyoc (1974), Dakar (1975) and Lima (1975), as well as on the UN-Charta of the economic rights and duties of states (1974), and on the results of the 7. Special General Assembly of the UN (1975).

The DC have no clear and consistent conceptions for a new international economic order. In the first place they demand better conditions for the integration of their economies into the existing (although asymmetric and discriminating) international division of labour; they call for higher trade incomes as a result of an intensified and liberalized world trade, for higher and stable prices for their raw materials and for more financial and technological aid. Not confrontation and "dissociation" (of their economies from the capitalistic world market) are the aims of their collecting bargaining, but industrial cooperation with the metropoles and liberalization of the world trade.

In substance there are no basic contradictions (although in form) between the conceptions for development of the political elites in DC and the global interests of the multinational corporations - the main promoters of the "internationalization of production" (cf. the "scramble for incentives") since World War II - , although the results of the penetration processes by MNC for DC are alarming.

After all the integration of the DC into the world market, speeded up by political bargaining, strengthens the existing economic world order, notwithstanding the permanent modifications of the international division of labour (industrialization via import substitution in DC, export-diversification etc.). Furthermore the internationalized political elites in DC become more and more interested in the benefits (trade incomes) of the existing capitalistic world system.

The liberalization of the world trade results in a stronger polarization between the five groups ("types") of developing countries. Only few countries with great mineral and other resources and with large internal markets have the preconditions for becoming industrialized "submetropoles". Their pattern of development is economic growth cum (technological) dependence. 